\title{
Media Pembelajaran Interaktif Bahasa Inggris Kelas V Sekolah Dasar Negeri 02 Cinere
}

\author{
Alya Riski Nursifa ${ }^{1}$, Amelia Orinda ${ }^{2}$, Safira Salsabila Pritanti ${ }^{3}$ \\ ${ }_{1,2,3}$ Teknik Informatika dan Komputer, Politeknik Negri Jakarta \\ Jl. Prof. Dr. G.A Siwabessy, Kampus Baru UI, Beji, Kukusan, Beji, Kota Depok, Jawa Barat 16424 \\ alya.nursifa.tik13@mhsw.pnj.ac.id ${ }^{1}$, ameliaorinda95@gmail.com², safirapritanti@yahoo.com³
}

\begin{abstract}
Abstrak - Sekolah Dasar adalah awal jenjang pendidikan formal yang diterapkan di Indonesia yang ditempuh selama 6 tahun, yaitu mulai dari kelas satu hingga kelas enam. Pelajar sekolah dasar pada umumnya berusia diantara 7-12 tahun, dalam usia inilah, pendidikan mengenai Bahasa Inggris harus mulai diperkenalkan kepada anak sejak jenjang Sekolah Dasar. Media Pembelajaran Interaktif adalah suatu media yang terdiri dari banyak komponen atau media yang terhubung satu sama lain dan mampu berinteraksi antara pengguna dan komputer. Pengajaran media dalam bentuk media interaktif memiliki kemampuan untuk menyimpan audio visual data, membuat media interaktif sebagai pendukung metode pembelajaran konvensional yang dulu disampaikan melalui buku dianggap kurang mudah dicerna oleh siswa, sehingga diharapkan pemanfaatan media interaktif yang bertujuan untuk membantu meningkatkan minat belajar siswa sekolah dasar dapat menjelaskan bahwa media pembelajaran interaktif mampu memberikan informasi dengan lebih menarik dan menyenangkan.
\end{abstract}

Kata kunci Media Pembelajaran, Bahasa Inggris, Multimedia, Adobe Flash, metodologi Luther.

\section{PENDAHULUAN}

Kemajuan teknologi pada era globalisasi telah meluas di berbagai bidang dan menjadikan pengetahuan mudah di akses. Salah satunya pada bidang pendidikan, siswa dapat menggunakan komputer sebagai sarana media pembelajaran interaktif. Media pembelajaran interaktif diterapkan pada Sekolah Dasar salah satunya adalah media pembelajaran interaktif mata pelajaran Bahasa Inggris. Pada jenjang pendidikan Sekolah Dasar secara umum siswa melakukan interaksi dengan guru hanya menggunakan media buku. Media pembelajaran interaktif digunakan sebagai motivasi bagi mereka untuk mengeksplorasi berbahasa inggris pada tataran lebih lanjut dengan menggunakan media bantuan komputer.

Pembelajaran Bahasa Inggris pada jenjang pendidikan Sekolah Dasar secara umum siswa melakukan interaksi dengan guru hanya menggunakan media buku namun belum efisien. Sehingga media pembelajaran yang sudah diterapkan melalui buku kurang menarik perhatian siswa dalam pembelajaran Bahasa Inggris. Adanya pembaruan dalam proses belajar mengajar antara siswa dan guru di kelas melalui media interaktif dapat membantu guru menarik perhatian siswa untuk belajar Bahasa Inggris dalam proses belajar mengajar.

Dalam menarik perhatian belajar mengajar siswa Sekolah Dasar media interaktif ini dapat membantu guru dalam menyampaikan materi pembelajaran dan juga dapat membantu siswa dapat memahami materi dengan konten lebih menarik dan mudah dipahami siswa. Dalam media pembelajaran interktif ini siswa ditekankan untuk aktif dalam menjawab pertanyaan yang telah di tampilkan dalam game interaktif ini, sehingga diharapkan siswa dapat belajar aktif dalam memahami pelajaran Bahasa Inggris.

Berdasarkan hal-hal diatas, maka dibuatlah media pembelajaran game interaktif Bahasa Inggris kelas V Sekolah Dasar sebagai sarana bantuan media belajar guru untuk siswa.

\section{LANDASAN TEORI}

A. Media Pembelajaran

Menurut Sadiman (2008) menjelaskan bahwa media pembelajaran adalah segala sesuatu yang dapat digunakan untuk menyalurkan pesan dari pengirim ke penerima pesan. Dalam hal ini adalah proses merangsang pikiran, perasaan, perhatian, dan minat serta perhatian siswa sehingga proses belajar dapat terjalin. Berdasarkan pernyataan tersebut dapat disimpulkan bahwa media pembelajaran adalah alat bantu yang digunakan oleh guru sebagai alat bantu mengajar. Dalam interaksi pembelajaran, guru menyampaikan pesan ajaran berupa materi pembelajaran kepada siswa.

\section{B. Education Game}

Education game merupakan sebuah permainan yang dibuat untuk mengajarkan pengguna mengenai pembelajaran tertentu, konsep dari education game merupakan melatih pemahaman serta nalar dalam motivasi memaikan game. (Hurd dan Jenuings, 2009). 


\section{Adobe Flash}

Adobe Flash adalah perangkat lunak keluaran Adobe yang di gunakan keperluan multimedia umumnya Adobe Flash digunakan untuk pemuatan animasi tapi selain itu, aplikasi ini dapat digunakaan untuk merancang dan membuat sebuah web dan media pembelajaran interaktif. (M. Amrullah Akbar et al, 2008).

\section{Metode Pengembangan Luther-Sutopo.}

Metode pengembangan Luther-Sutopo merupakan sebuah model pengembangan aplikasi multimedia. Pada metode ini terdiri dari enam tahapan, yaitu :

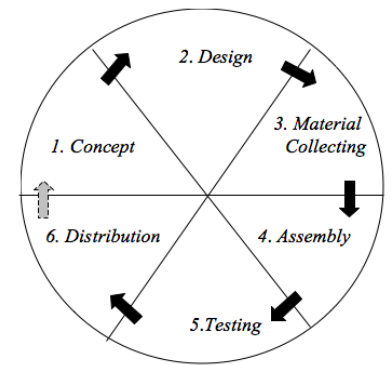

Gambar 1. Tahapan Metode Luther-Sutopo.

\section{ANALISA DAN PERANCANGAN}

Metodologi Luther merupakan salah satu metode pengembangan multimedia. Metodologi luther dikarenakan untuk megefisiensi waktu yang diberikan serta keuntungan yang lainnya yaitu tahapan yang kompleks dan mendukung dalam media pembelajaran interaktif. Metodologi Luther memiliki enam tahapan, yaitu: konsep (concept), desain (design), pengumpulan material (material collecting), pembuatan (assembly), pengujian (testing), dan distribusi (distribution).

\section{A. Konsep (Concept)}

Tahap konsep yaitu menentukan tujuan, termasuk identifikasi audiens, macam aplikasi ( presentasi, interaktif, dan lain-lain), tujuan aplikasi (informasi, hiburan, pelatihan, dan lain-lain), dan spesifikasi umum.

Pada Media Pembelajaran Game Interaktif Bahasa Inggris Kelas V Sekolah Dasar sasaran audiens ditunjukkan untuk tingkat / kelas V Sekolah Dasar dan Guru Bahasa Inggris kelas V Sekolah Dasar. Untuk mengidentifikasi kebutuhan pengguna terhadap pembuatan aplikasi media pembelajaran game interaktif berbasis multimedia yaitu dengan melakukan wawancara kepada pihak sekolah yang bersangkutan, yaitu guru bahasa Inggris kelas V Sekolah Dasar Negeri 02 Cinere.

Media Pembelajaran Game Interaktif Bahasa Inggris Kelas $\mathrm{V}$ Sekolah Dasar menghasilkan aplikasi berbentuk game interaktif yang didalamnya terdapat beberapa soal tentang Grammar, dan Vocabulary. Media pembelajaran dilengkapi dengan musik dan gambar Interface 2D yang interaktif sehingga dapat menarik siswa untuk menggunakan media pembelajaran ini dan menambah minat belajar siswa.

Tujuan pembuatan aplikasi media pembelajaran game interaktif Bahasa Inggris kelas $\mathrm{V}$ Sekolah Dasar adalah membuat siswa termotivasi dalam belajar Bahasa Inggris dan membantu guru berkomunikasi dalam proses belajar mengajar agar lebih mudah dan tidak membosankan dengan menampilkan konten pembelajaran dalam bentuk animasi yang menarik.

\section{B. Desain (Design)}

Perancangan storyboard dalam aplikasi Media Pembelajaran Game Interaktif Bahasa Inggris kelas V Sekolah Dasar terdiri beberapa halaman, diantaranya:

\begin{tabular}{|c|c|c|}
\hline No & $\begin{array}{l}\text { Scene } \\
\text { Name }\end{array}$ & Deskripsi \\
\hline 1. & Intro & $\begin{array}{l}\text { Halaman intro merupakan } \\
\text { halaman awal, di halaman ini } \\
\text { terdapat animasi objek yang } \\
\text { bergerak serta tombol navigasi } \\
\text { yaitu tombol start untuk } \\
\text { melanjutkan ke menu serta } \\
\text { music instrument sebagai } \\
\text { background music. }\end{array}$ \\
\hline 2. & menu & $\begin{array}{l}\text { Halaman menu merupakan } \\
\text { halaman yang menyajikkan } \\
\text { beberapa sub-menu materi } \\
\text { vocabulary, play, exercise, credit } \\
\text { di halaman ini terdapat animasi } \\
\text { objek yang bergerak serta } \\
\text { tombol navigasi yaitu tombol } \\
\text { vocabulary, play, exercise, credit } \\
\text { untuk melanjutkan ke sub-menu, } \\
\text { tombol rumah untuk kembali ke } \\
\text { home, tombol sound untuk } \\
\text { menonaktifkan suara, serta } \\
\text { terdapat music instrument } \\
\text { sebagai background music. }\end{array}$ \\
\hline 3. & $\begin{array}{l}\text { Sub- } \\
\text { menu } \\
\text { vocab } \\
\text { ulary }\end{array}$ & $\begin{array}{l}\text { Halaman sub-menu vocabulary } \\
\text { merupakan halaman yang } \\
\text { menyajikkan beberapa bagian } \\
\text { materi color, occupation, dan } \\
\text { family di halaman ini terdapat } \\
\text { animasi objek yang bergerak } \\
\text { serta tombol navigasi yaitu } \\
\text { tombol color, occupation, dan } \\
\text { family untuk melanjutkan ke isi } \\
\text { konten materi, tombol rumah } \\
\text { untuk kembali ke home, tombol }\end{array}$ \\
\hline
\end{tabular}




\begin{tabular}{|c|c|c|}
\hline & & $\begin{array}{l}\text { sound untuk menonaktifkan } \\
\text { suara, serta terdapat music } \\
\text { instrument sebagai background } \\
\text { music. }\end{array}$ \\
\hline & $\begin{array}{l}\text { Sub- } \\
\text { menu } \\
\text { materi } \\
\text { play }\end{array}$ & $\begin{array}{l}\text { Halaman sub-menu play } \\
\text { merupakan halaman yang } \\
\text { menyajikkan beberapa bagian } \\
\text { materi color, occupation, dan } \\
\text { family di halaman ini terdapat } \\
\text { animasi objek yang bergerak dan } \\
\text { bila cursor diarahkan ke icon } \\
\text { gambarnya akan menampilkan } \\
\text { suara sesuai dengan yang dipilih. } \\
\text { serta tombol navigasi yaitu } \\
\text { tombol color, occupation, dan } \\
\text { family untuk melanjutkan ke isi } \\
\text { konten materi, tombol rumah } \\
\text { untuk kembali ke home, tombol } \\
\text { sound untuk menonaktifkan } \\
\text { suara, serta terdapat music } \\
\text { instrument sebagai background } \\
\text { music. }\end{array}$ \\
\hline 4. & $\begin{array}{l}\text { Sub- } \\
\text { menu } \\
\text { materi } \\
\text { exerci } \\
\text { se }\end{array}$ & $\begin{array}{l}\text { Halaman sub-menu exercise } \\
\text { merupakan halaman yang } \\
\text { menyajikkan beberapa bagian } \\
\text { materi color, occupation, dan } \\
\text { family di halaman ini terdapat } \\
\text { tersedia soal pilihan ganda dan } \\
\text { ila sudah sampai nomor terakhir } \\
\text { akan muncul hasil nilainya. serta } \\
\text { tombol navigasi yaitu tombol } \\
\text { color, occupation, dan family } \\
\text { untuk melanjutkan ke isi konten } \\
\text { materi, tombol rumah untuk } \\
\text { kembali ke home, tombol sound } \\
\text { untuk menonaktifkan suara, } \\
\text { serta terdapat music instrument } \\
\text { sebagai background music. }\end{array}$ \\
\hline 5. & $\begin{array}{l}\text { Sub- } \\
\text { menu } \\
\text { materi } \\
\text { credit }\end{array}$ & $\begin{array}{l}\text { Halaman sub-menu credit } \\
\text { merupakan halaman yang } \\
\text { menyajikkan keterangan } \\
\text { developer aplikasi. terdapat } \\
\text { tombol navigasi yaitu tombol } \\
\text { color, occupation, dan family } \\
\text { untuk melanjutkan ke isi konten } \\
\text { materi, tombol rumah untuk } \\
\text { kembali ke home, tombol sound } \\
\text { untuk menonaktifkan suara, } \\
\text { serta terdapat music instrument } \\
\text { sebagai background music. }\end{array}$ \\
\hline
\end{tabular}

\section{Pengumpulan Material (Material Collecting)} Adapun pada tahap pengumpulan bahan untuk pembuatan aplikasi Media Pembelajaran Game Interaktif Bahasa Inggris kelas V Sekolah Dasar yaitu gambar, teks, animasi dan suara sesuai dengan kebutuhan untuk aplikasi.
Sementara itu pengumpulan materi diambil dari buku paket Bahasa Inggris Sekolah Dasar Kelas V dan gambar yang diunduh kemudian diedit sehingga sesuai dengan kebutuhan dalam format .png atau .jpg serta audio didapat dari hasil rekaman untuk contoh pembacaan materi dalm format.wav.

\section{IMPLEMENTASI DAN PENGUJIAN}

A. Pembuatan (Assembly)

Tahap pembuatan (assembly) adalah tahapan dimana keseluruhan elemen multimedia yang telah dikumpulkan di tahap sebelumnya diseleksi dan digabung menjadi satu kesatuan aplikasi multimedia. Pembuatan aplikasi ini berpedoman yang sudah dirancang di tahap design.

Dibawah ini merupakan contoh dari tampilan menu awal dan menu exercise pada aplikasi.

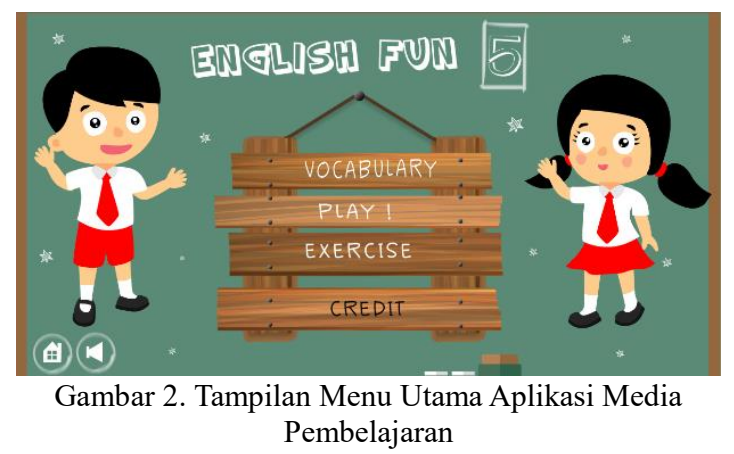

Terdapat tiga menu utama, selanjutnya pengguna dapat memilih menu apa yang ingin di pelajari diantara menu vocabulary, play, dan exercise.

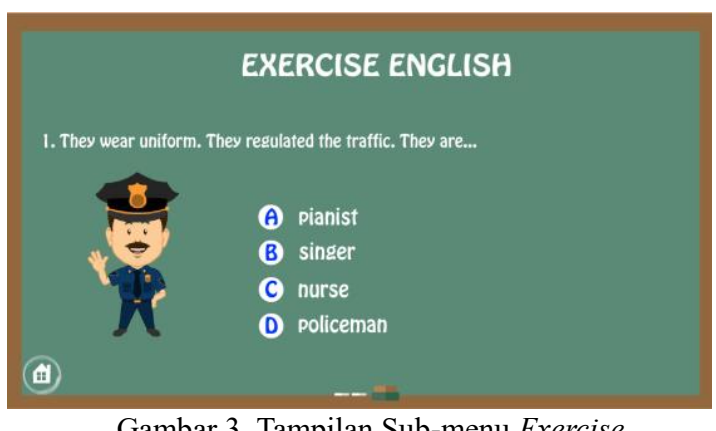

Gambar 3. Tampilan Sub-menu Exercise

Dalam menu ini, pengguna akan di beri sepuluh soal Bahasa Inggris yang akan di jawab sampai akhir dengan format pilihan ganda, yaitu dengan mengklik opsi abjad pada jawaban ataupun keterangannya, lalu setelah memilih jawaban, dengan otomatis halaman akan berganti ke soal selanjutnya. 


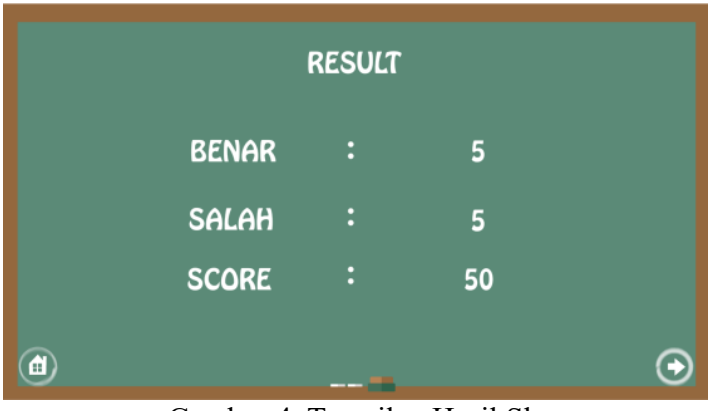

Gambar 4. Tampilan Hasil Skor

Setelah pengguna selesai menjawab seluruh pertanyaan yang ada di sub-menu exercise, selanjutnya akan muncul keterangan jumlah skor yang benar, skor yang salah, dan perolehan jumlah skor seluruhnya.

\section{B. Pengujian (Testing)}

Pengujian aplikasi Media Pembelajaran Game Interaktif Bahasa Inggris kelas V Sekolah Dasar melalui pengajuan kuisioner kepada user setelah user mencoba menjalankan aplikasi Media Pembelajaran Game Interaktif Bahasa Inggris kelas V Sekolah Dasar. Untuk mengetahui tanggapan dan penilaian pemain terhadap media pembelajaran ini, telah disebarkan kuesioner kepada 28 responden. Rumus skala likert digunakan untuk mengolah hasil kuisioner.

Keterangan

$$
P=\frac{S}{\text { skorideal }} \times 100 \%
$$

$\mathrm{P}$ : Nilai presentase yang dicari

$\mathrm{S}$ : Jumlah frekuensi dikalikan dengan nilai yang ditetapkan jawaban

Skorideal : Nilai tertinggi dikalikan dengan jumlah sampel

100\% : Bilangan tetap

1. Penilaian tampilan dan fitur yang menarik sebagai media pembelajaran yang interaktif

\begin{tabular}{|c|l|l|l|l|}
\hline $\begin{array}{c}\text { Pert } \\
\text { any } \\
\text { aan }\end{array}$ & Keterangan & Skor & $\begin{array}{l}\text { Freku } \\
\text { ensi }\end{array}$ & S \\
\hline \multirow{3}{*}{1} & Sangat Setuju & 3 & 25 & 75 \\
\cline { 2 - 5 } & Setuju & 2 & 3 & 6 \\
\cline { 2 - 5 } & Tidak Setuju & 1 & 0 & 0 \\
\hline \multirow{2}{*}{$\begin{array}{l}\text { Jum } \\
\text { lah }\end{array}$} & & & $\mathbf{2 8}$ & $\mathbf{8 1}$ \\
\hline
\end{tabular}

$$
P=\frac{81}{84} \times 100 \%=96,4 \%
$$

2. Penilaian ketepatan materi pada aplikasi English Fun 5

\begin{tabular}{|l|l|l|l|l|}
\hline $\begin{array}{l}\text { Pert } \\
\text { any } \\
\text { aan }\end{array}$ & Keterangan & Skor & $\begin{array}{l}\text { Freku } \\
\text { ensi }\end{array}$ & S \\
\hline
\end{tabular}

\begin{tabular}{|c|l|l|l|l|}
\hline \multirow{3}{*}{2} & Sangat Setuju & 3 & 23 & 69 \\
\cline { 2 - 5 } & Setuju & 2 & 5 & 10 \\
\cline { 2 - 5 } & Tidak Setuju & 1 & 0 & 0 \\
\hline \multirow{2}{*}{$\begin{array}{l}\text { Jum } \\
\text { lah }\end{array}$} & & & $\mathbf{2 8}$ & $\mathbf{7 9}$ \\
\hline
\end{tabular}

$$
P=\frac{79}{84} \times 100 \%=94 \%
$$

3. Penilaian fungsi aplikasi English Fun 5 dalam

\begin{tabular}{|c|c|c|c|c|}
\hline $\begin{array}{l}\text { Pert } \\
\text { any } \\
\text { aan }\end{array}$ & Keterangan & Skor & $\begin{array}{l}\text { Freku } \\
\text { ensi }\end{array}$ & $\mathrm{S}$ \\
\hline \multirow{3}{*}{3} & Sangat Setuju & 3 & 21 & 63 \\
\hline & Setuju & 2 & 7 & 14 \\
\hline & Tidak Setuju & 1 & 0 & 0 \\
\hline $\begin{array}{l}\text { Jum } \\
\text { lah }\end{array}$ & & & 28 & 77 \\
\hline
\end{tabular}
membantu siswa kelas V SDN 02 Cinere dalam memahami materi Bahasa Inggris

4. Penilaian aplikasi English Fun 5 terhadap motivasi siswa untuk belajar Bahasa Inggris

\begin{tabular}{|c|l|l|l|l|}
\hline $\begin{array}{c}\text { Pert } \\
\text { any } \\
\text { aan }\end{array}$ & Keterangan & Skor & $\begin{array}{l}\text { Freku } \\
\text { ensi }\end{array}$ & S \\
\hline \multirow{3}{*}{4} & Sangat Setuju & 3 & 20 & 60 \\
\cline { 2 - 5 } & Setuju & 2 & 8 & 16 \\
\cline { 2 - 5 } & Tidak Setuju & 1 & 0 & 0 \\
\hline \multirow{2}{*}{$\begin{array}{l}\text { Jum } \\
\text { lah }\end{array}$} & & & $\mathbf{2 8}$ & $\mathbf{7 6}$ \\
\hline
\end{tabular}

$$
P=\frac{76}{84} \times 100 \%=90,4 \%
$$

5. Penilaian tentang kesulitan dalam menjalankan aplikasi media pembelajran English Fun 5

\begin{tabular}{|c|l|l|l|l|}
\hline $\begin{array}{c}\text { Pert } \\
\text { any } \\
\text { aan }\end{array}$ & Keterangan & Skor & $\begin{array}{l}\text { Freku } \\
\text { ensi }\end{array}$ & S \\
\hline \multirow{3}{*}{5} & Sangat Setuju & 3 & 5 & 15 \\
\cline { 2 - 5 } & Setuju & 2 & 5 & 10 \\
\cline { 2 - 5 } & Tidak Setuju & 1 & 20 & 20 \\
\hline \multirow{2}{*}{$\begin{array}{l}\text { Jum } \\
\text { lah }\end{array}$} & & & $\mathbf{2 8}$ & $\mathbf{4 5}$ \\
\hline
\end{tabular}

$$
P=\frac{45}{84} \times 100 \%=53,5 \%
$$

*) bermakna bahwa aplikasi English Fun 5 tidak memiliki kesulitan bagi penggunanya. 
6. Penilaian kesesuaian soal excercise dengan materi yang terdapat pada English Fun 5

\begin{tabular}{|c|l|l|l|l|}
\hline $\begin{array}{c}\text { Pert } \\
\text { any } \\
\text { aan }\end{array}$ & Keterangan & $\begin{array}{l}\text { Sko } \\
\mathrm{r}\end{array}$ & $\begin{array}{l}\text { Freku } \\
\text { ensi }\end{array}$ & S \\
\hline \multirow{3}{*}{6} & Sangat Setuju & 3 & 19 & 57 \\
\cline { 2 - 5 } & Setuju & 2 & 9 & 18 \\
\cline { 2 - 5 } & Tidak Setuju & 1 & 0 & 0 \\
\hline \multirow{2}{*}{$\begin{array}{l}\text { Jum } \\
\text { lah }\end{array}$} & & & $\mathbf{2 8}$ & $\mathbf{7 5}$ \\
\hline
\end{tabular}

$$
P=\frac{75}{84} \times 100 \%=89,2 \%
$$

7. Penilaian kepuasan aplikasi English Fun 5

\begin{tabular}{|c|l|l|l|l|}
\hline $\begin{array}{c}\text { Perta } \\
\text { nyaan }\end{array}$ & Keterangan & Skor & $\begin{array}{l}\text { Freku } \\
\text { ensi }\end{array}$ & S \\
\hline \multirow{3}{*}{7} & $\begin{array}{l}\text { Sangat } \\
\text { Setuju }\end{array}$ & 3 & 17 & 51 \\
\cline { 2 - 5 } & Setuju & 2 & 11 & 22 \\
\cline { 2 - 5 } & Tidak Setuju & 1 & 0 & 0 \\
\hline $\begin{array}{l}\text { Jumla } \\
\text { h }\end{array}$ & & & $\mathbf{2 8}$ & $\mathbf{7 3}$ \\
\hline
\end{tabular}

$$
P=\frac{73}{84} \times 100 \%=86,9 \%
$$

Setelah mengolah kuisioner diatas menggunakan rumus skala Likert dari 28 responden yang terdiri dari end-user pada saat exhibition dan tentunya Guru Bahasa Inggris kelas V SDN 02 Cinere, memiliki hasil nilai kuisioner diatas rata-rata $80 \%$, maka dapat disimpulkan bahwa aplikasi English Fun 5 sudah cukup memenuhi keinginan dari pengguna termasuk Guru Bahasa Inggris SDN 02 Cinere.

\section{Distribusi (Distribution)}

Distribusi dilakukan setelah aplikasi ini dinyatakan layak digunakan oleh pengguna media pembelajaran interaktif ini, maka aplikasi ini disimpan dalam format aplikasi Windows-Android atau yang lebih dikenal Windroid (.exe) serta sudah dijadikan file autoplay.

\section{KESIMPULAN DAN SARAN}

\section{A. Kesimpulan}

Hal-hal yang dapat disimpulkan dari pembuatan aplikasi Media Pembelajaran Game Interaktif Bahasa Inggris kelas V Sekolah Dasar adalah :

1. Proses pengembangan aplikasi Media Pembelajaran Game Interaktif Bahasa Inggris kelas V Sekolah Dasar dilakukan dengan enam tahapan prosedur pengembangan, yaitu (1) concept (konsep), (2) design (desain), (3) material collecting (pengumpulan bahan), (4) assembly (pembuatan), dan (5) testing (pengujian), dan Distribution (distribusi).

2. Media Pembelajaran Game Interaktif ini diharapkan dapat membuat siswa-siswi SDN 02 Cinere tertarik sehingga paham materi bahasa inggris kelas V.

3. Media Pembelajaran Game Interaktif ini cukup dapat memberikan hiburan yang edukatif tentang berbahasa Inggris yang interaktif.

4. Berdasarkan hasil pengujian alpha dan beta yang telah dilalui, bahwa aplikasi English Fun 5 telah memenuhi konsep yang diharapkan pengguna.

B. Saran

Saran untuk aplikasi Media Pembelajaran Game Interaktif Bahasa Inggris kelas V Sekolah Dasar diharapkan pengembangan kedepannya sebagai berikut :

1. Disarankan aplikasi pembelajaran selanjutnya dapat menambahkan fitur search untuk mencari materi yang diingginkan user.

2. Aplikasi Media Pembelajaran Game Interaktif dapat menambahkan video conversation yang dapat membantu siswa-siswi SDN 02 Cinere dalam melancarkan komunikasi verbal berbahasa Inggris.

\section{REFERENSI}

[1] Binanto, I., 2010. Multimedia Digital - Dasar Teori dan Pengembangannya. Yogyakarta: Andi.

[2] Arief S Sadiman, dkk. 2008. Media pendidikan. Jakarta : PT Raja Grafindo. Persada.

[3] Hurd, Daniel dan Jenuings, Erin. 2009. Standardized Educational Games Ratings : Suggested Criteria. Karya Tulis Ilmiah

[4] M. Amrullah Akbar, Zaki Rahim. 2008. Making. Educational Animation Usung Flash. Bandung: penerbit Informatika

[5] Bustaman, Burmansyah (2001). Web design dengan macromedia flash mx 2004. Yogyakarta: Andi Offset.

[6] Miller, D. C., \& Salkind, N. J. (2002). Handbook of research design \& social measurement. Thousand Oaks, Calif: Sage Publications. 